\title{
Use of BIM scenarios by operations services to work with the building information model
}

\author{
Natalia Knyazeva ${ }^{1, *}$ and Daria Levina ${ }^{1}$ \\ ${ }^{1}$ Moscow State University of Civil Engineering, Yaroslavskoe shosse, 26, Moscow, 129337, Russia
}

\begin{abstract}
Information systems with ever-growing and increasingly complex functionality are being actively introduced into the operation services. In the process of development, the information technology finds new ways to improve efficiency of economic activities for enterprises. However, the use of automated operation control systems in the absence of representation of the construction object as a single system leads to an increase in labor costs and resource losses. There are inefficiently used operation facilities of the maintenance services that have to be solved, including energy efficiency. Many experts of operation do not have enough skills to interact with information model. There is a need to expand the application of BIM beyond construction and design, to learn to use the information obtained at these stages. Automated data collection of BIM can solve such problems with the help of BIM scenario or BIM-use. Each set of works with information about the stage of the life cycle of the project and part of project in international practice is called BIM scenarios. In general, the use of BIM scenarios and information modeling (IM) shows a composite, yet little-researched activity that can provide the necessary effect in maintenance, operation, document management, checking the energy efficiency of the building.
\end{abstract}

\section{Introduction}

Work on building information modeling (BIM) is progressing rapidly both at the level of design companies and expert organizations, and at the level of state regulation. Domestic regulation that integrates foreign experience and Russian specificity in construction design are being developed. More and more often there are examples of successful application of information models (MI) in the preparation and the construction of production itself. However, the topic of interoperability of design and BIM with real estate management systems and with building operation systems in general is pressing and still poorly studied. Existing local solutions for the organization of information exchange with CRM, FM systems are applied chaotically at the stage of solving individual problems of technical maintenance or management of rental space. Such ways of integration of software environments have mostly one-way communication and do not return changes to the primary information model.

\footnotetext{
*Corresponding author: nknyazeva@mgsu.ru
} 
Relatively speaking, BIM in the operational phase causes the presence of three main components:

1. Tools that are used while working on the object of operation (implementing the process of processing information about the construction site at this stage).

2. Skills, knowledge about the work and management of these resources.

3. Operations or processes that are solved by means of tools.

Based on these components, it is clear that the construction of a common system of TIM (Technologies of information modeling) integration at the stage of operation should begin with the solution of individual operations and building discrete processes.

The analysis of the existing literature in this field showed that the authors speak about a poor understanding of technologies, about the lack of common accepted standards and methods of building maintenance services [1,2]. V. Sharmanov in his work [2] writes about the lack of interest of our government in the application of technology despite the fact that since 2017 the Ministry of construction and housing, communal and civil construction (Ministry of construction of Russia) has adopted the idea of developing TIM. Also V. V. Sharmanov calls one of the reasons - slow introduction of TIM programs in educational institutions. Time is flying, technology is developing, and as a conclusion, we see a gap between education and real time.

The next thing should be mentioned is the article of V. V. Talapov [3]. The specialist argues on the basic principles that are necessary for the successful use of BIM technology:

1. The single model principle

2. The principle of pragmatism

3. The principle of consistent modeling

These principles are important, in particular, for the integration the information systems of operating services with the information model of the building.

Our aim is to learn how to use the data obtained at the previous stages of construction project life cycle and operation services, and to be able to synthesize them with the procedures and amount of work at this stage.

Now we do not often use the concept of Bim-use or Bim-scenario, which is just one of the elements of BIM-technology.Bim-scenario is divided into separate phases and stages of project development in the framework of information modeling, where each scenario includes its own sequence of tasks. The existing decomposition at the stages of operation of the facility is a means to improve the development of this stage, if it is combined with information systems used by organizations. According to the author [4], the use of all BIMscenarios involves a high complexity of the project with a large amount of data and such systems need classification (Classifier, MDS) and management (BEP, Data Management).

To achieve the desired result, we need high-quality integration of BIM project with information systems, technologies that are used by enterprises. For example, it is important to have a single CDE (Common Data Environment). It provides a connection between all participants in the development process IM for the exchange of data. The next important point is the model development specification (MDS) associated with the classifiers. Currently, Russia does not have a united accepted classification system, so that some companies are forced to use foreign ones and rewrite them for themselves. These are systems such as Omniclass and UniClass. This method is not reasonable and effective, because foreign systems are based on the elements, components and materials themselves. For example, the code in Revit Omniclass in the USA indicates the number of the material [5]. While our system should be related to the GASN, FER, it means to have a link to the technologies of construction production.

As a result, we get a specified model and it is able to meet both EIR (customer requirements) and BIM scenario requirements [4] a Well-structured EIR will help provide the right information to optimize operational costs and utility usage to provide long-term 
sustainability. After that - the document management systems, the BMS (building management systems), the energy management systems, etc. Quite often enterprises do not use automated information systems and prefer human labor for the reasons described above. Krystyna Araszkiewicz in her article [6] writes about the main advantages associated with the use of information and data included in the BIM building functioning model. Transferring the flow of information from a BIM model to a Facility Management (FM) system is more efficient than the manual data entry that exists in FM practice. That is possible in already integrated system. The use of automated systems can substantially speed up a variety of issues thanks to the accuracy of the model credentials, fuel and material savings, risk reduction in management, providing security and the possibility of building management [7].

\section{Goals and objectives}

The purpose of the study is to determine the possibility and effectiveness of the use of information modeling in BIM-scenarios at the steps of commissioning of the building and the operation itself.

The estimated characteristics are:

1. Cost reduction

2. Time saving

3. Efficient use of information

4. Automated control

\section{Materials and methods}

There is a system designed to meet each of the points of evaluation characteristics - CAFM (Computer Aided Facility Management). Its use began almost three decades ago and at the same time, it is still very narrowly used in Russia. CAFM allows not only to manage the property during the operation, but also to solve the money issues, to form technical base for the research subject, etc [8]. In fact, these programs perform the role of Manager, but with larger efficiency in comparison with a human beeing. To interact with CAFM we need to compile data from the classification system OmniClass Table 31- Phases and 33 Disciplines in sections of operation with the stages of investment and development of the project (table1), which were identified, based on Russian Standard, Law of the Russian Federation, Federal Law dated December 30, 2009 No. 384-FZ "Technical Regulations on the Safety of Buildings and Structures" and foreign documentation- system OmniClass Table 31 - Phases (table.2). The OmniClass Construction Classification System (known as OmniClass ${ }^{\mathrm{TM}}$ or OCCS) is a classification system for the construction industry. The classification was developed in the USA.

Table 1. The list of disciplines of investment and development project for commissioning and operation of the building.

\begin{tabular}{|c|c|l|}
\hline Discipline & OmniClass code & \multicolumn{1}{c|}{ Description } \\
\hline $\begin{array}{c}\text { Quality Assurance } \\
\text { (QA) }\end{array}$ & $33-255100$ & $\begin{array}{l}\text { Oversight and coordination of all planning, implementation, } \\
\text { and supervision of the project quality control plan. May also } \\
\text { include working with employees as well as outside agencies } \\
\text { or consultants involved in inspections and testing of } \\
\text { construction practices.. }\end{array}$ \\
\hline $\begin{array}{c}\text { Heating, Ventilation, } \\
\text { and Air- } \\
\text { Conditioning }\end{array}$ & $33-55242117$ & $\begin{array}{l}\text { Maintenance and operation related to heating, ventilation, air } \\
\text { conditioning and other services. }\end{array}$ \\
\hline
\end{tabular}




\begin{tabular}{|c|c|l|}
\hline $\begin{array}{c}\text { Operation and } \\
\text { Maintenance (HVA) }\end{array}$ & Proposal Preparation \\
(PP) & $33-251400$ & $\begin{array}{l}\text { administering private and government funds and contracts, } \\
\text { tracking proposals and writing proposals and other } \\
\text { documentation. May also include ensuring that proposals in } \\
\text { progress are in compliance with instructions, managing } \\
\text { production and the distribution of all work documents. }\end{array}$ \\
\hline $\begin{array}{c}\text { Facility Use } \\
\text { Disciplenes }\end{array}$ & $33-550000$ & $\begin{array}{l}\text { Continued maintenance, operation and use of a building, } \\
\text { structure, or site following the completion of construction. }\end{array}$ \\
\hline Real Estate (RE) & $33-551400$ & Buying selling or renting of property. \\
\hline $\begin{array}{c}\text { Facility Owner } \\
\text { (ROw) }\end{array}$ & $33-552100$ & $\begin{array}{l}\text { Ownership of property and facilitating all expenses } \\
\text { associated with all aspects of procurement, design, } \\
\text { construction, and facility use. }\end{array}$ \\
\hline $\begin{array}{c}\text { Facility Operations } \\
\text { (FOp) }\end{array}$ & $33-552400$ & $\begin{array}{l}\text { Providing a combination of support services within a client's } \\
\text { facilities, such as janitorial, maintenance, trash disposal, } \\
\text { guard and security, mail routing, reception, laundry, and } \\
\text { related services to support operations within facilities. }\end{array}$ \\
\hline $\begin{array}{c}\text { Facility Restoration } \\
\text { Services (FRS) }\end{array}$ & $33-553600$ & $\begin{array}{l}\text { Cleaning, maintaining and repairing of damage to parts of } \\
\text { building due to age, weather, or materials deterioration. }\end{array}$ \\
\hline
\end{tabular}

Table 2. The stages of the investment-development project.

\begin{tabular}{|c|c|l|}
\hline Stage & Code & \multicolumn{1}{c|}{ Description } \\
\hline $\begin{array}{c}\text { Entering into } \\
\text { Exploitation } \\
\text { (Commissioning }\end{array}$ & 09 & $\begin{array}{l}\text { Evaluation of completed work through testing, inspection and } \\
\text { commissioning (including all equipment) to ensure compliance with } \\
\text { design criteria, efficiency in accordance with applicable standards and } \\
\text { standards. Transfer of executive documentation from the team of } \\
\text { designers and builders to the user management group of the facility, and } \\
\text { demonstrations, training and instructions. }\end{array}$ \\
\hline Exploitation & 10 & $\begin{array}{l}\text { At this stage, the user or lessee occupies a useful area, manages the } \\
\text { systems of the facility, uses and services it, including repairs }\end{array}$ \\
\hline
\end{tabular}

We deal with different information about the project at each step of development. Working with it is a sequence of steps that can be performed separately or simultaneously. Information processing techniques are substantial at each single stage. We may have different goals, which imply different types of work with data: search and collection, systematization, conversion of information to the type we need, the actual use of the generated data, the choice of storage format. This system of work is important for the task. So, to implement the data we have to classify Bim-scenarios for the studied stages, as the author did [9].

01. Information collection

02. Formation of information

03. Information analysis

04. Exchange of information

05. Introduction of information

Each category has its own subcategory of the type of interaction with information, as stated in the work. [9].

Let us form a set of BIM-scenarios, as proposed by N. In.Knyazeva [10]. Our stages do not involve the release of such documentation as the General construction plan, architectural design, etc., so we will use the disciplines from Omniclass. For example, let us 
take the investment and development project for the services of the exhibition center (EC) (table.3).

Bim-scenarios are coded the following way:

1. The first two pairs indicate the stage of project development ( in our case, it is commissioning and operation)

2. The next two pairs indicate the category and subcategory of the work with information.

3. Last acronym for the discipline of Omniclass.

Table 3. BIM-scenarios of the stage of operation and commissioning on the example of the exhibition center (EC).

\begin{tabular}{|c|c|c|c|}
\hline Code & Description & Tool & Integration with the information model \\
\hline $\begin{array}{l}09-03- \\
03- \\
\text { HVA }\end{array}$ & $\begin{array}{l}\text { Measuring work and } \\
\text { comparison with the } \\
\text { information model of the } \\
\text { EC. }\end{array}$ & $\begin{array}{l}\text { Laser scanner } \\
\text { FARO Focus } \\
\text { S150; } \\
\text { 3D scanner } \\
\text { Leica } \\
\text { ScanStation } \\
\text { C10 }\end{array}$ & $\begin{array}{l}\text { Integration by means of the CYCLONE } \\
\text { software package and its built-in Model } \\
\text { module. }\end{array}$ \\
\hline $\begin{array}{l}09-03- \\
03- \\
\text { QA }\end{array}$ & $\begin{array}{l}\text { Verification of the EC object } \\
\text { for heat loss and entering } \\
\text { data into the information } \\
\text { model }\end{array}$ & $\begin{array}{l}\text { Thermal } \\
\text { imaging system }\end{array}$ & $\begin{array}{l}\text { To integrate the of use FLIR QuickPlot and } \\
\text { FLIR ResearchIR software, where } \\
\text { there is a possibility to export graphics in } \\
\text { standard formats (CSV, bmp, jpg) }\end{array}$ \\
\hline $\begin{array}{l}\text { 09-03- } \\
03-\text { PP }\end{array}$ & $\begin{array}{l}\text { Approval of documents for } \\
\text { certain types of work on the } \\
\text { information model of the } \\
\text { EC; Binding permits }\end{array}$ & $\begin{array}{c}\text { Bentley } \\
\text { ProjectWise }\end{array}$ & $\begin{array}{l}\text { Integration through SQL-queries based on } \\
\text { XML- documents. }\end{array}$ \\
\hline $\begin{array}{l}\text { 10-01- } \\
01-\mathrm{RE}\end{array}$ & $\begin{array}{l}\text { The input of information } \\
\text { into the database on leased } \\
\text { and purchased spaces }\end{array}$ & $\begin{array}{l}\text { MS Exel } \\
\text { MS Access } \\
\text { «Baz.Ar.» }\end{array}$ & $\begin{array}{l}\text { The SQL-query in the Revit information } \\
\text { model according to space ( to the required } \\
\text { characteristics of the area, lighting, etc.), } \\
\text { transfer the generated database in the form of } \\
\text { an XML-document or providing access to the } \\
\text { project using the API-driver or the ODBC. }\end{array}$ \\
\hline $\begin{array}{l}10-01- \\
03- \\
\text { FOw }\end{array}$ & $\begin{array}{l}\text { Checking the flow in water } \\
\text { systems for billing to tenants }\end{array}$ & $\begin{array}{l}\text { The primary } \\
\text { sensors; } \\
\text { calculators, data } \\
\text { acquisition and } \\
\text { transmission } \\
\text { devices; } \\
\text { server ACYB }\end{array}$ & $\begin{array}{l}\text { ETL-data storage method. Extracting the } \\
\text { initial information and transformation through } \\
\text { the suitable format into the destination } \\
\text { repository. }\end{array}$ \\
\hline $\begin{array}{l}10-05- \\
03- \\
\text { FRS }\end{array}$ & $\begin{array}{l}\text { Accounting of equipment for } \\
\text { reconstruction and repair }\end{array}$ & $\begin{array}{l}1 \mathrm{C} \\
\text { KORUSkonsalti } \\
\text { ng }\end{array}$ & $\begin{array}{l}\text { Integration with } 1 \mathrm{C} \text { based on ESB; } \\
\text { Electronic document flow is locally possible } \\
\text { using customer equipment, in the cloud using } \\
\text { Microsoft Azure, or in the cloud using } \\
\text { Microsoft Office } 365 \text {; }\end{array}$ \\
\hline $\begin{array}{l}10-05- \\
04- \\
\text { FOp }\end{array}$ & $\begin{array}{l}\text { Monitoring of security } \\
\text { system }\end{array}$ & PO «Intellekt» & $\begin{array}{l}\text { The complex can be integrated with other } \\
\text { systems through an open architecture. } \\
\text { Configuration, management and monitoring of } \\
\text { systems is carried out both from a centralized } \\
\text { point and from remote workplaces. }\end{array}$ \\
\hline $\begin{array}{c}10-05- \\
04- \\
\text { FRS }\end{array}$ & $\begin{array}{l}\text { Monitoring of technical } \\
\text { condition of building } \\
\text { structures }\end{array}$ & ZETlab & $\begin{array}{l}\text { Extraction of the information using IFC } \\
\text { format and place it in COBie format. }\end{array}$ \\
\hline
\end{tabular}

Each Bim-scenario is a subcategory of the studied final stages of implementation. This table proposes the idea of integrating the software and other tools used with the information model of the object. For the operation, the exhibition center requires greater attention to repair, technical safety and verification. 
In scenario 09-03-03-HVA, the measurement comparison is possible by importing data in ASCII, DXF, and a specially designed data transfer format between Cyclone and AutoCAD (Autodesk Corp., USA) or MicroStation (Bentley Systems, Inc., USA.) There is also a possibility to convert to $\mathrm{CAD}$ compatible formats.

Integration, as in the scenario 09-03-03-QA by exporting data in the cvs format, makes it possible to check heat losses on the information model of the EC by extracting data from tables on problem areas on the internal facades and on the internal part of the object

The discipline "Checking the flow in water systems for billing to tenants " uses a method of ETL data storage. Many ETL solutions require personal servers, processing methods, databases, and licenses. A key drawback of the ETL concept is that at the very beginning of the process someone has to decide what information is important, what data needs to be updated, what information should be exluded and who has rights to this data [11-12]. After that, data warehouses or master data management systems become the repositories.

The question arises: where and how we will extract the necessary data for the operation service. It is proposed to use the COBie format, which has already had a successful practice in the US in the construction of buildings for the army. COBie makes it possible to organically use the information obtained during the development of the project with BIM technology. And this, in turn, gives a chance to find application to this format in the operation and maintenance of the buildings. The next step is an automated project management, the control of completeness of information with the help of CAFM system. Now COBie is a part of the national BIM standard - United States (NBIMS-US), which provides information on the construction assets needed for successful facility maintenance and management. COBie is an open standard, so that asset management information systems (CAFM) can import COBie data and fill data fields. This saves managers quite a lot of time compared to manual input and information search [13].

Speaking about information exchange, there are standards ISO, IFD, IFC, IDM,MVD [14].Their correct application and use allows information exchange between stakeholders involved in the asset lifecycle, as they represent a universal framework that serves as the basis for new methods of sharing and storing COBie information .

While monitoring the technical condition of building structures, information exchange is conducted by exctracting data from the information model of the international IFC format and placing it in COBie (it can be placed as an Exel file format). COBie is designed to store and transmit all essential data for the operational phase. COBie is seen as one of the solution that would simplify the transfer of information from BIM systems into CAFM systems. Its goal is to improve the way he captures information on the stages and ensure management. The authors of the article tell that Preserving information throughout the lifecycle of buildings is important for effective facility management and end-of-life decisions for buildings. The advantage of COBie is that it can be viewed not only in several BIM applications, but also in simple spreadsheet. This versatility allows the use of COBie regardless of size and technological sophistication.

\section{Results}

The purpose of the organization of BIM-scenarios with the operation is to meet the mentioned performance characteristics (cost reduction, time saving, efficient use of information, automated control). After analyzing the ideas of Bim-scenarios in conjunction with the classifiers, we can notice the benefits of BIM and underline the necessity of integration of automated systems with the information model. However, there are inconveniences that need to be addressed for successfully interaction with the technology:

1. To determine the relationship and sequence of the BIM scenarios. 
2. To develop a common methodology for interacting with BIM scenarios.

3. To develop a common accepted classifier.

4.Linking BIM software to an application for operation, we will get such advantages and benefits as:

5. The creation real-time links between the BIM model and operations applications (FM) in a single environment (cloud).

6. The data connection at all stages of housing and communal services and building maintenance plans.

7. Space management

8. Publication a BIM-model in an FM application allowing everyone in the project team to visualize and manage the information model.

9. Synchronization properties (families) of BIM model with maintenance service.

\section{Conclusion}

BIM technology is gaining successful experience in implementing various tasks along the life cycle. The interoperability of design and construction information modeling technologies with building management systems in general is extremely important and still poorly researched. This study can serve as a source for the requirements model, to encourage the promotion of data and information transfer between BIM and FM, to induce the establishment of a process of integration of BIM in FM, providing a clear conception of the relationship between the parties involved.

\section{References}

1. A.N. Astafieva, J.A. Kibireva, I.L. Vasileva, Construction of Unique Buildings and Structures 59, 8 (2017)

2. V.V. Sharmanov, A.E. Mamaev, A.S. Boleiko, J.S. Zolotova, Construction of Unique Buildings and Structures 37, 10 (2015)

3. V. Talapov, CAD and Graphics 238, 8 (2016)

4. I. Emelyanov, isicad.ru: all about CAD and PLM 142, 11 (2016)

5. O. Pakidov, isicad.ru: all about CAD and PLM 125, 13 (2014)

6. K. Araszkiewicz, Procedia Engineering 196, 1034-1042 (2017)

7. A.V. Demenev, A.S. Artamonov, Naukovedeniye 7, 3 (2015)

8. P. Poór, N. Kuchtová, M. Šimon, Procedia Engineering 69, 1276-1280 (2014)

9. N.V. Knyazeva, Industrial and civil construction 9, 68-71 (2018)

10. S.H. Ali El-Sappagh, A.M. Ahmed Hendawi, A. Hamed El Bastawissy, Journal of King Saud University - Computer and Information Sciences 23, 91-104 (2011)

11. C. Xavier, F. Moreira, Procedia Technology 9, 381-387 (2013)

12. N. Grishina, isicad.ru: all about CAD and PLM 159, 20 (2017)

13. V. Edmondson, M. Cerny, M. Lim, B. Gledson, J. Woodward, Automation in Construction 91, 193-205 (2018)

14. O.O. Akinade, L.O. Oyedele, S.O. Ajayi, M. Bilal, H.A. Alaka, H.A. Owolabi, O.O. Arawomo, Journal of Cleaner Production 180, 375-385 (2018) 